JAPAN. J. Genetics Vol. 45, No. 4: 261-268 (1970)

\title{
A MUTANT OF YEAST WITH TEMPERATURE SENSITIVE RESPIRATION
}

\author{
AKIRA UCHIDA AND KOHTA SUDA \\ Biology Division, Faculty of General Education, Kobe University, Kobe 657 \\ and \\ Department of Botany, Faculty of Science, Kyoto University Kyoto 606
}

Received March 23, 1970

Most vegetative (cytoplasmic) and segregational (nuclear) petite mutants of yeast which are unable to utilize nonfermentable substrates for growth show simultaneous deficiencies in certain mitochondrial enzymes including cytochromes $a$ and $b$ (Sherman and Slonimski 1964). It is well known that temperature sensitive and suppressor susceptible mutants have been powerful tools in recent work in microbial genetics. Under appropriate conditions, such mutations provide useful techniques for the study of geneprotein relationships. Thus, these mutants would be most desirable in the study of the respiratory system of yeast.

Temperature sensitive mutants of yeast have been reported with respect to growth (Hartwell 1967), an amino acid activating enzyme (Hartwell and McLaughlin 1968) and protoporphyrin synthesis (Gunge et al. 1967). This report describes our preliminary experiments on the isolation and characterization as well as the genetic analysis of a mutant of Saccharomyces cerevisiae with temperature sensitive respiration.

\section{MATERIALS AND METHODS}

Strain: A diploid strain a $\left(\frac{a, g a l, p a n}{@, \text { gal, pan }}\right)$ of Saccharomyces cerevisiae (Seno 1962) was used to isolate temperature sensitive mutants. Haploid strains used for genetic analysis were $a$-1C ( $a$, gal, pan) which was obtained by ascus dissection from the parental strain $a$, and C814-50B (a, ade 1, thr 4 ) which was kindly provided by Dr. T. Takahashi, Asahi Brewery Co.

Media: PY contained $10 \mathrm{~g}$ each of peptone and yeast extract per $1000 \mathrm{~m} l$ of deionized water. PYS and PYL contained $50 \mathrm{~g}$ of sucrose and $50 \mathrm{ml}$ of $70 \%$ Na-lactate, respective$1 \mathrm{y}$, in $1000 \mathrm{~m} l$ of PY. Liquid cultures were grown on a shaker unless stated otherwise. For anaerobiosis, cells were grown by bubbling nitrogen gas through liquid PYS enriched with ergosterol solution (Morpurgo et al. 1964). Nitrogen gas to be used was purified by passing through Fieser's solution. Spore forming medium contained $4 \mathrm{~g}$ of Na-acetate and $0.5 \mathrm{~g}$ of Na-glyoxalate in $1000 \mathrm{ml}$ of deionized water. To distinguish respiratorydeficient cells from respiratory-competent cells, two methods were applied. One was to see whether or not could cells grow in PYL. The other was color plate method (Nagai 1965). Respiratory-deficient colonies formed on the color plate turned dark purple whereas respiratory-competent ones turned faint purple. 
Isolation of temperature sensitive mutants: Cells of the strain $a$, precultured in liquid PYS for 2 days at $20^{\circ} \mathrm{C}$, were inoculated at a $1 / 100$ dilution in liquid PYL to which $N$ methyl- $N^{\prime}$-nitro- $N$-nitrosoguanidine (Nitrosoguanidine) was added at a final concentration of $10 \mu \mathrm{g} / \mathrm{ml}$. The culture was incubated at $20^{\circ} \mathrm{C}$ with bubbling air until stationary phase. Cells were then spread on PYS agar plate after appropriate dilutions and incubated for 3 days at $20^{\circ} \mathrm{C}$. The resulting colonies were replicated onto PYS and PYL agar plates. Among the colonies which formed on PYS but not on PYL plates at $30^{\circ} \mathrm{C}$, a mutant that showed temperature sensitivity with respect to respiration was isolated. The frequency was about $2 \times 10^{-5}$. This mutant has been designated as $a$-ts 1830 .

Spectrophotometric analysis of cytochrome and measurement of oxygen uptake: Spectrophotometric analysis was carried out with a Hitachi recording spectrophotometer according to the method of Huang et al. (1966). Oxygen uptake was measured by means of an oxygen electrode. For this purpose, cells were sampled at time intervals and washed with $\mathrm{M} / 15$ potassium phosphate buffer ( $\mathrm{pH} 6.8$ ). The washed cells $(3$ to $15 \mathrm{mg}$ dry weight) were suspended in $3 \mathrm{~m} l$ of the same buffer supplimented with a final concentration of $0.6 \%$ of glucose and incubated at $30^{\circ} \mathrm{C}$ in the presence of the electrode.

Genetic techniques: Diploid cells were cultured in PYS for 2 days at $20^{\circ} \mathrm{C}$ and transferred to spore forming medium. After 3 to 4 days of incubation at $20^{\circ} \mathrm{C}$ four-spored asci were dissected under a microscope by means of a De-Fonbrune type micromaniplater. A random spore analysis was performed according to the method of Hartwell (1967). For hybridization, cells of opposite mating type were grown separately in PYS for 2 days at $20^{\circ} \mathrm{C}$. A small amount of each culture was mixed on PYS plate with a platinum loop and incubated for 3 to 4 days. The diploidy was checked by the spore forming ability.

\section{RESULTS}

\section{Respiratory properties of a-ts 1830}

\section{A. Respiratory activity}

As shown in Table 1 , the respiratory activities of the parental strain $a$ and the mutant $a$-ts 1830 were comparable when both strains were grown in PYS at $20^{\circ} \mathrm{C}$. In contrast the respiratory activity of the mutant was reduced to approximately $1 / 4$ of that of the parental strain after grown in the same medium at $30^{\circ} \mathrm{C}$. The effect of temperature on the respiratory activity of the mutant was further investigated. The mutant cells were grown in PYS for 24 hours at both $20^{\circ} \mathrm{C}$ and $30^{\circ} \mathrm{C}$, then transferred to PYS and to $\mathrm{M} / 15$ potassium phosphate buffer ( $\mathrm{pH}$ 6.8). Oxygen uptake of each culture was measured at the time of tranfer $\left(0\right.$ hour) and after 27 hours of incubation at both $20^{\circ} \mathrm{C}$ and $30^{\circ} \mathrm{C}$. The results shown in Table 2 indicate that the respiratory activity of the mutant depends on the growth temperature and that the temperature shift itself has no effect on it when no growth occurred.

The mutant cells, previously grown at $20^{\circ} \mathrm{C}$ or $30^{\circ} \mathrm{C}$, were streaked on the color plates (See MATERIALS AND METHODS), followed by incubation at $20^{\circ} \mathrm{C}$ and $30^{\circ} \mathrm{C}$. It was observed that all the colonies formed at $20^{\circ} \mathrm{C}$ were faint purple but those formed at $30^{\circ} \mathrm{C}$ were dark purple, independent of the temperatures of the precultures. This 
Table 1. Respiratory activities of $a$-ts1830 and its parental strain $a$

\begin{tabular}{c|c|ccc}
\hline \multirow{2}{*}{ Strain } & \multicolumn{2}{c}{ cultural condition } & $\mathrm{QO}_{2}$ \\
& temperature $(\mathrm{C})$ & time $(\mathrm{h})$ & $\left(\mu l \mathrm{O}_{2}\right.$ uptake/mg dry weight/h $)$ \\
\hline$a$-ts1830 & 30 & 25 & 42.4 \\
$a$-ts1830 & 20 & 38 & 143.2 \\
$a$ & 30 & 25 & 160.4 \\
$a$ & 20 & 52 & 149.8 \\
\hline
\end{tabular}

Table 2. Effect of temperature shift on $\mathrm{QO}_{2}$ of $a$-ts 1830

(a)

precultured for $24 \mathrm{~h}$ at $20^{\circ} \mathrm{C}$

(b) precultured for $24 \mathrm{~h}$ at $30^{\circ} \mathrm{C}$

\begin{tabular}{|c|c|c|c|c|c|c|c|c|}
\hline time $(h)$ & medium & temperature $(\mathrm{C})$ & $\mathrm{QO}_{2}$ & time $(\mathrm{h})$ & medium & temperature & (C) & $\mathrm{QO}_{2}$ \\
\hline 0 & - & - & 142.2 & 0 & - & - & & 34.5 \\
\hline 27 & PYS & 20 & 151.6 & 27 & PYS & 20 & & 137.7 \\
\hline 27 & PYS & 30 & 39.1 & 27 & PYS & 30 & & 34.5 \\
\hline 27 & buffer & 20 & 158.6 & 27 & buffer & 20 & & 37.7 \\
\hline 27 & buffer & 30 & 151.5 & 27 & buffer & 30 & & 39.6 \\
\hline
\end{tabular}

observation leads to a conclusion that the reduced respiratory activity of the mutant would not result from the induction of petite mutants during growth at $30^{\circ} \mathrm{C}$.

B. Absorption spectra of cytochromes

The respiratory-deficient mutants ordinally have altered patterns of cytochromes (Sherman and Slonimski 1964). To see the cytochrome patterns of $a$-ts1830, the mutant cells were grown in PYS for 17 hours at both $20^{\circ} \mathrm{C}$ and $30^{\circ} \mathrm{C}$. They were collected by centrifugation and subjected to spectrophotometry. As shown in Fig. 1, cytochrome $c$ $(550 \mathrm{~m} \mu)$ is apparent in the culture grown at either $20^{\circ} \mathrm{C}$ or $30^{\circ} \mathrm{C}$. On the other hand, it can be seen that smaller amounts of cytochromes $b(562 \mathrm{~m} \mu)$ and $a(602 \mathrm{~m} \mu)$ are present in the culture at $30^{\circ} \mathrm{C}$ than those at $20^{\circ} \mathrm{C}$.

\section{Respiratory adaptation}

Yeast cells grown under an anaerobic condition are known to have little respiratory activity. The cells are transferred to an aerobic condition, then the respiratory activity improves gradually. This phenomenon is called respiratory adaptation (Slonimski 1953). The effect of temperature on the respiratory adaptation of $a$-ts 1830 was examined. The mutant cells were anaerobically grown for 44 hours at $20^{\circ} \mathrm{C}$ or for 24 hours at $30^{\circ} \mathrm{C}$, and then respiratory adaptation was commenced at $20^{\circ} \mathrm{C}$ and $30^{\circ} \mathrm{C}$ by replacing nitrogen gas by air. At time intervals samples were withdrawn to determine oxygen uptake. The results are shown in Fig. 2. Although the values of $\mathrm{QO}_{2}$ were rather high for anaerobic cultures, the respiratory activity increased during the aerobic incubation at either $30^{\circ} \mathrm{C}$ or $20^{\circ} \mathrm{C}$ after grown anaerobically at $20^{\circ} \mathrm{C}$. It increased little, however, after grown anaerobically at $30^{\circ} \mathrm{C}$.

The progressive alterations of absorption spectra during the respiratory adaptation 


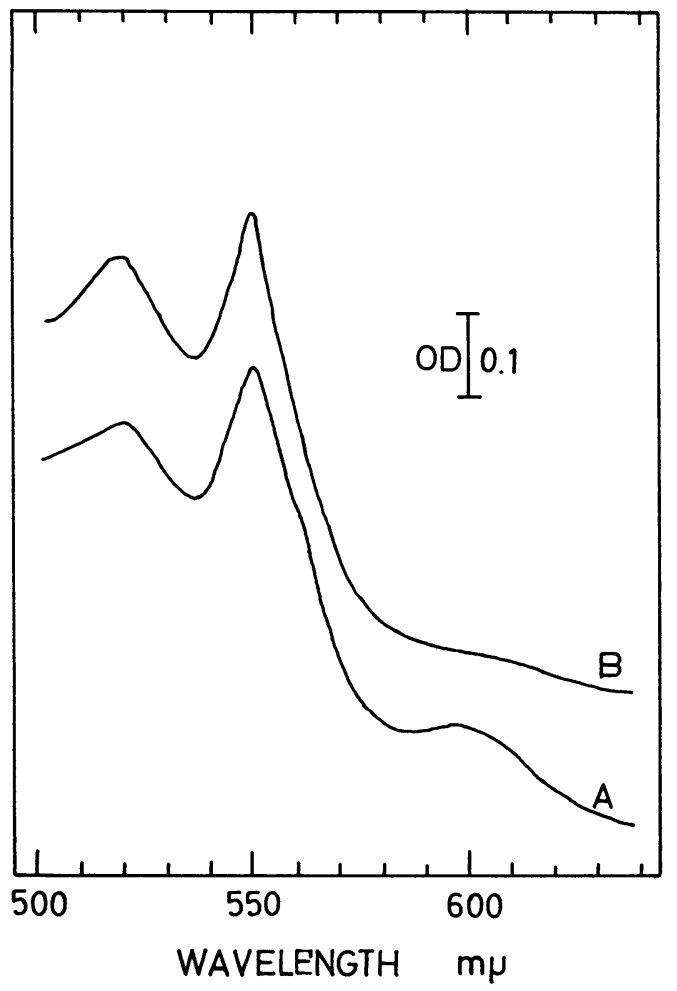

Fig. 1. Absorption spectra of $a$-ts 1830 cells grown at $20^{\circ} \mathrm{C}$ and $30^{\circ} \mathrm{C}$. Cells, aerobically grown for 17 hours at $20^{\circ} \mathrm{C}$ (A) and at $30^{\circ} \mathrm{C}(\mathrm{B})$, were collected by centrifugation and spectrophotometric analysis was carried out with a Hitachi recording spectrophotometer according to the method of Huang et al. (1966).

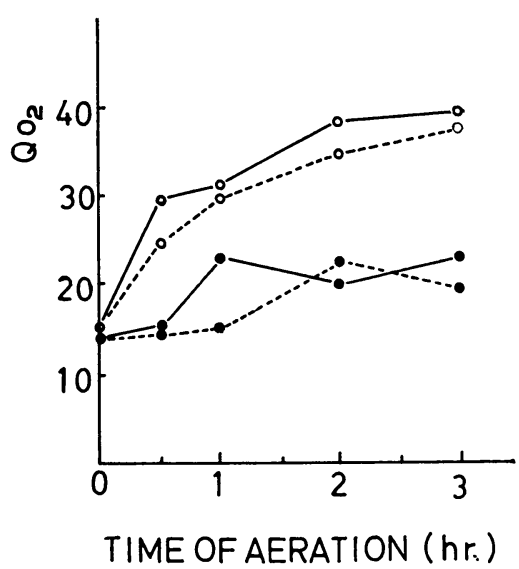

Fig. 2. Development of respiratory activities of $a$-ts 1830 cells during aerobic adaptation. Cells were anaerobically grown for 44 hours at $20^{\circ} \mathrm{C}$ (O) and for 24 hours at $30^{\circ} \mathrm{C}(\mathbf{0})$ and then aerated at $20^{\circ} \mathrm{C}(-)$ and at $30^{\circ} \mathrm{C}(--)$. Samples were taken at time intervals, and $\mathrm{QO}_{2}\left(\mu l \mathrm{O}_{2}\right.$ uptake/mg dry weight/hour) was measured polarographically.

are presented in Figs. 3 and 4 . The mutant cells were anaerobically precultured for 20 hours at $20^{\circ} \mathrm{C}$ (Fig. 3) and for 15 hours at $30^{\circ} \mathrm{C}$ (Fig. 4), and introduced to air. It is seen that cytochrome $c(550 \mathrm{~m} \mu)$ was synthesized by the cells precultured at both $20^{\circ} \mathrm{C}$ and $30^{\circ} \mathrm{C}$; cytochromes $b(562 \mathrm{~m} \mu)$ and $a(602 \mathrm{~m} \mu)$ seemed to be synthesized only after grown at $20^{\circ} \mathrm{C}$.

\section{Genetic analyses of a-ts 1830}

To see the genetic properties of the mutant $a$-ts 1830,3 tetrads were analyzed. All the four-segregants from each ascus showed the temperature sensitivity with respect to. respiration, the character of which has been designated as $\mathrm{RC}^{\mathrm{ts}}$. This indicates that the mutant $a$-ts 1830 would be a homozygous diploid for the gene concerned.

One of the segregants, ats1830-1A (@), obtained above, was crossed with the respiratory-competent strain, $\mathrm{C} 814-50 \mathrm{~B}(a)$, the character of which has been designated as $\mathrm{RC}^{+}$. The cross gave rise to respiratory-competent diploid cells.

The diploid, derived from the cross ats1830-1A (@, ade +$) \times \mathrm{C} 814-50 \mathrm{~B}$ (a, ade 1), was subjected to tetrad analysis. The result is shown in Table 3. The markers of mating. 


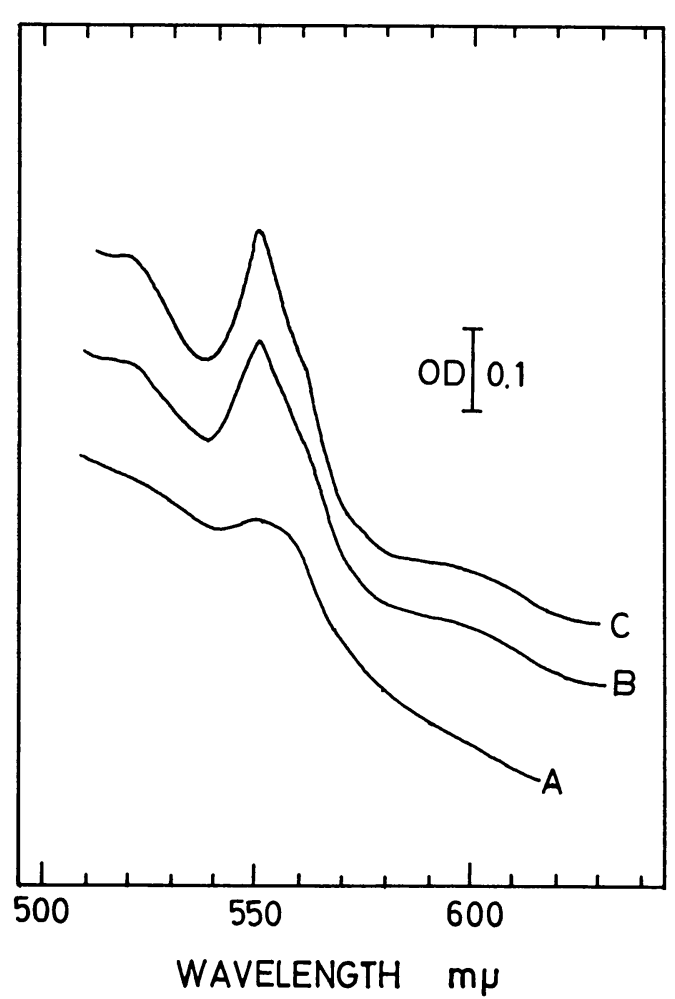

Fig. 3. Absorption spectra before and after aeration of anaerobic $a$-ts 1830 cells grown at $20^{\circ} \mathrm{C}$. Cells were anaerobically grown at $20^{\circ} \mathrm{C}$ for 20 hours and then aerated at $20^{\circ} \mathrm{C}$ and $30^{\circ} \mathrm{C}$. A; before aerobic adaptation, B; after 3 hours' aeration at $20^{\circ} \mathrm{C}, \mathrm{C}$; after 3 hours' aeration at $30^{\circ} \mathrm{C}$.

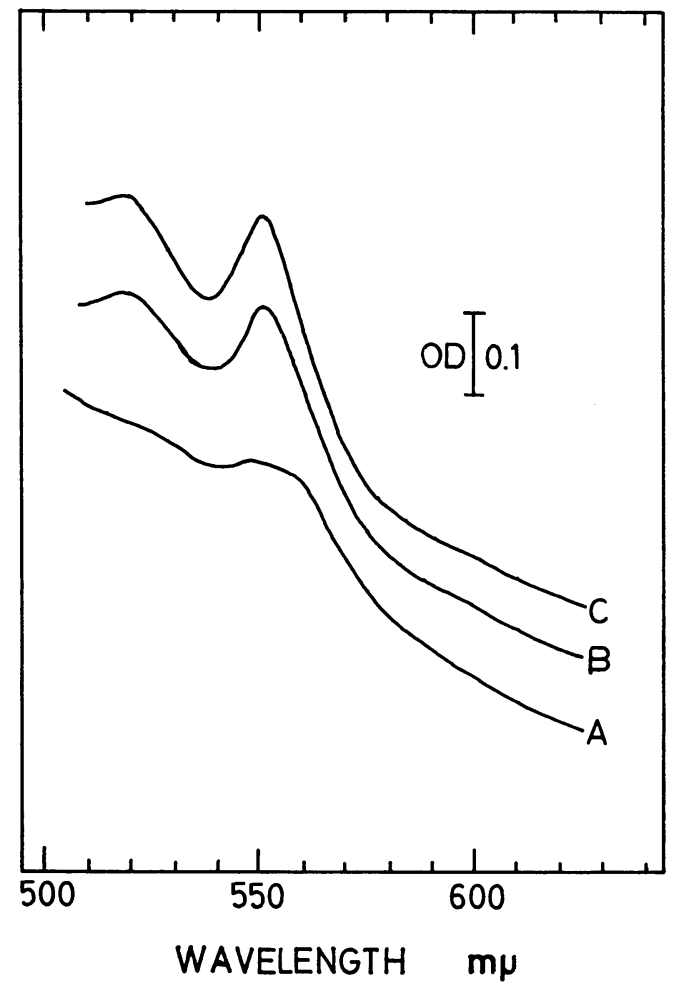

Fig. 4. Absorption spectra before and after aeration of anaerobic $a$-ts 1830 cells grown at $30^{\circ} \mathrm{C}$. Cells were anaerobically grown at $30^{\circ} \mathrm{C}$ for 15 hours and then aerated at $20^{\circ} \mathrm{C}$ and $30^{\circ} \mathrm{C}$. $\mathrm{A}$; before aerobic adaptation, $\mathrm{B}$; after 3 hours' aeration at $20^{\circ} \mathrm{C}, \mathrm{C}$; after 3 hours' aeration at $30^{\circ} \mathrm{C}$.

type and adenine requirement showed 2 to 2 segregation. However, the temperature sensitivity with respect to respiration segregated irregularly. Namely, in addition to $\mathrm{RC}^{+}$and $\mathrm{RC}^{\mathrm{ts}}$ there brought forth a new type of segregants, designated as $\mathrm{RC}^{-}$. These new segregants could grow well in PYS but not at all in PYL at both $20^{\circ} \mathrm{C}$ and $30^{\circ} \mathrm{C}$. One of the $\mathrm{RC}^{-}$segregants, 2A $(a)$ shown in Table 3, was backcrossed to ats $1830-1 \mathrm{~A}$ (@). The phenotype of the resulting diploids was $\mathrm{RC}^{\mathrm{ts}}$. The tetrad analysis of $5 \mathrm{com}$ plete asci showed that the segregation ratio of $\mathrm{RC}^{\text {ts }}$ to $\mathrm{RC}^{-}$was 2 to 2 , and the ratio was 20 to 17 by the random spore analysis. These results suggest that two nuclear genes are responsible for the irregular segregation for the respiratory activity.

A question arose, then, as to whether the two mutations which were closely related with each other were induced simultaneously by the treatment with nitrosoguanidine. To see this point the following analyses were performed. The strain $a$-1C $(a)$ which was obtained by ascus dissection from the parental strain $a$ was crossed with the segregant $a$-ts1830-1A (@), and 6 complete asci from the resulting diploids which were $\mathrm{RC}^{+}$ 
Table 3. Tetrad analysis of cross, ats1830-1A (@, ade $\left.e^{+}\right) \times$C814-50B (a, ade 1$)$

\begin{tabular}{|c|c|c|c|c|c|c|c|}
\hline & & & \multirow{3}{*}{$\begin{array}{l}\text { phenotype } \\
\text { concerning } \\
\text { respiration }\end{array}$} & & & & \multirow[b]{2}{*}{ phenotype } \\
\hline & \multicolumn{2}{|c|}{ genotype } & & & \multicolumn{2}{|c|}{ genotype } & \\
\hline & $\begin{array}{l}\text { mating } \\
\text { type }\end{array}$ & adenine & & & $\begin{array}{l}\text { mating } \\
\text { type }\end{array}$ & adening & $\begin{array}{l}\text { concerning } \\
\text { respiration }\end{array}$ \\
\hline $1 \mathrm{~A}$ & @ & - & $\mathrm{RC}^{\mathrm{ts}}$ & $5 \mathrm{~A}$ & $@$ & + & $\mathrm{RC}^{+}$ \\
\hline $1 \mathrm{~B}$ & $a$ & + & $\mathrm{RC}^{+}$ & $5 \mathrm{~B}$ & $a$ & + & $\mathrm{RC}^{+}$ \\
\hline $1 \mathrm{C}$ & $@$ & - & $\mathrm{RC}^{\mathrm{ts}}$ & $5 \mathrm{C}$ & @ & - & $\mathrm{RC}^{-}$ \\
\hline $1 \mathrm{D}$ & $a$ & + & $\mathrm{RC}^{+}$ & $5 \mathrm{D}$ & $a$ & - & $\mathrm{RC}^{\mathrm{ts}}$ \\
\hline $2 \mathrm{~A}$ & $a$ & - & $\mathrm{RC}^{-}$ & $6 \mathrm{~A}$ & $@$ & - & $\mathrm{RC}^{+}$ \\
\hline $2 \mathrm{~B}$ & $@$ & + & $\mathrm{RC}^{+}$ & $6 \mathrm{~B}$ & @ & - & $\mathrm{RC}^{\mathrm{ts}}$ \\
\hline $2 \mathrm{C}$ & $@$ & + & $\mathrm{RC}^{+}$ & $6 \mathrm{C}$ & $a$ & + & $\mathrm{RC}^{+}$ \\
\hline $2 \mathrm{D}$ & $a$ & - & $\mathrm{RC}^{\mathrm{ts}}$ & $6 \mathrm{D}$ & $a$ & + & $\mathrm{RC}^{\mathrm{ts}}$ \\
\hline $3 \mathrm{~A}$ & $a$ & + & $\mathrm{RC}^{+}$ & $7 \mathrm{~A}$ & $a$ & + & $\mathrm{RC}^{+}$ \\
\hline $3 \mathrm{~B}$ & $@$ & - & $\mathrm{RC}^{\mathrm{ts}}$ & $7 \mathrm{~B}$ & $@$ & - & $\mathrm{RC}^{-}$ \\
\hline $3 \mathrm{C}$ & $a$ & - & $\mathrm{RC}^{\mathrm{ts}}$ & $7 \mathrm{C}$ & $a$ & + & $\mathrm{RC}^{+}$ \\
\hline $3 \mathrm{D}$ & $@$ & + & $\mathrm{RC}^{+}$ & $7 \mathrm{D}$ & $@$ & - & $\mathrm{RC}^{\text {ts }}$ \\
\hline $4 \mathrm{~A}$ & @ & + & $\mathrm{RC}^{+}$ & $8 \mathrm{~A}$ & $@$ & - & $\mathrm{RC}^{+}$ \\
\hline $4 \mathrm{~B}$ & $@$ & + & $\mathrm{RC}^{\mathrm{ts}}$ & $8 \mathrm{~B}$ & $a$ & - & $\mathrm{RC}^{-}$ \\
\hline $4 \mathrm{C}$ & $a$ & - & $\mathrm{RC}^{+}$ & $8 \mathrm{C}$ & $a$ & + & $\mathrm{RC}^{\mathrm{ts}}$ \\
\hline $4 \mathrm{D}$ & $a$ & - & $\mathrm{RC}^{\mathrm{ts}}$ & $8 \mathrm{D}$ & @ & + & $\mathrm{RC}^{+}$ \\
\hline
\end{tabular}

were dissected. It was observed that all the segregation ratios of $\mathrm{RC}^{+}: \mathrm{RC}^{\mathrm{ts}}$ were $2: 2$. Moreover, the ratio was $21: 23$ by the random spore analysis. The cross of $a-1 \mathrm{C}(a)$ with an $\mathrm{RC}^{-}$segregant $5 \mathrm{C}$ (@) shown in Table 3, produced also $\mathrm{RC}^{+}$diploids. The random spore analysis of the resulting diploids showed the segregation ratio of $\mathrm{RC}^{+}: \mathrm{RC}^{\text {ts }}$ : $\mathrm{RC}^{-}$to be $36: 14: 22$. These results suggest that the parental strain had been endured with one mutation (mod gene for temperature sensitivity; see DISCUSSION) of the two before the treatment with nitrosoguanidine.

\section{DISCUSSION}

It could be possible to assume that the temperature sensitivity with respect to respiration of yeast would result from one of the following changes of a certain protein; (1) an enzyme or structure which participates in the replication or retention of cytoplasmic gene (rho) could neither have its function nor be synthesized at high temperature, (2) an enzyme concerning respiration could not have its catalytic activity at high temperature and (3) one of the proteins requisite to the respiratory assembly of mitochondrial enzymes could not be synthesized or even if synthesized at high temperature it would be abnormally formed having lost its function.

The case of $a$-ts 1830 would not be (1) because of the fact that the colonies formed at $20^{\circ} \mathrm{C}$ after grown at $30^{\circ} \mathrm{C}$ showed respiratory-competent phenotype. The mutant cells, grown at $20^{\circ} \mathrm{C}$ under an aerobic condition, retained their respiratory activity 
during a longer period of incubation in nongrowing medium at $30^{\circ} \mathrm{C}$ (Table 2a). One may say, therefore, that (2) would be also inadequate to elucidate the mutant characteristics. From the observations described here the following explanation seems to be most likely, i.e., a protein concerning respiration could be normally synthesized at low temperature but once it was synthesized at high temperature, it would have partially lost the ability to make normal assembly of respiratory system unless growth so occurred at low temperature as to dilute out the protein synthesized at high temperature.

The genetic analyses suggest a two-gene segregation for the respiratory activity of the mutant $a$-ts 1830 . As for the two mutations, it might be possible to assume that one would be a segregational petite mutation (pet) and the other a "modifier gene" mutation $(m o d)$ which causes the temperature sensitive respiration when the pet mutation was present in the genome. Assuming the above hypothetical genes, the genotypes of the strains used in the cross could be postulated as follows; $a-1 \mathrm{C}(a$, pet+, mod), ats1830-1A (@, pet, mod), C814-50B (a, pet,$+ \bmod +)$ and 2A \& 5C $(a$, pet, mod +$)$ \&(@, pet, mod + ), respectively.

The tetrad analysis of the mutant $a$-ts1830 revealed that all the segregants were $\mathrm{RC}^{\mathrm{ts}}$. Hence the genotype of $a$-ts 1830 would be postulated to be $\left(\frac{a, \text { pet, mod }}{@ \text {, pet, mod }}\right)$. Since nitrosoamides were reported to enhance the frequency of mitotic recombination in yeast (Zimmerman at al. 1966), one could further assume that the pet + to pet mutation was first induced, followed by mitotic recombination in the presence of nitrosoguanidine, producing a homozygous diploid.

On the basis of the biochemical and genetic data described here, the gene-protein relationship might be such that a protein which is requisite to make assembly of respiratory system could not be synthesized due to the pet mutation. But the modified protein which is functional at low temperature but not at high temperature could be synthesized by the action of the mod gene.

\section{SUMMARY}

A temperature sensitive mutant of Saccharomyces cerevisiae was isolated with partially defective respiratory activity at high temperature. The respiratory activity of the mutant was reduced to approximately $1 / 4$ of the parental strain after grown at $30^{\circ} \mathrm{C}$, and it could be improved to be normal after grown at $20^{\circ} \mathrm{C}$. Spectrophotometric analysis showed that the mutant could synthesize only small amounts of cytochromes $b$ and $a$ at $30^{\circ} \mathrm{C}$. Genetic analyses revealed that two gene mutations for the respiratory activity of the mutant were involved.

\section{ACKNOWLEDGMENT}

The authors are indebted to Dr. T. Minagawa of Kyoto University for his valuable advices during the course of this study. 


\section{LITERATURE CITED}

Gunge, N., T. Sugimura, and M. Iwasaki, 1967 Genetic analysis of a respiration-deficient mutant of Saccharomyces cerevisiae lacking all cytochromes and accumulating coproporphyrin. Genetics 57: 213-226.

Hartwell, L. H., 1967 Macromolecule synthesis in temperature-sensitive mutants of yeast. J. Bacteriol. 93: 1662-1670.

Hartwell, L. H., and C. S. McLaughlin, 1968 Mutants of yeast with temperature-sensitive isoleucyltRNA synthetases. Proc. Natl. Acad. Sci. U.S. 59: 422-428.

Huang, M., D. R. Biggs, G. D. Clark-Warker, and A. W. Linnane, 1966 Chloramphenicol inhibition of the formation of particulate mitochondrial enzymes of Saccharomyces cerevisiae. Biochim. Biophys. Acta 114: 434-436.

Morpurgo, G., G. Serlupi-Crescenzi, G. Tecce, F. Valente, and D. Venettacci, 1964 Influence of ergosterol on the physiology and the ultra-structure of Saccharomyces cerevisiae. Nature 201: 897-899.

Nagai, S., 1965 Variety of diagnostic dye mixtures for respiration deficiency in yeast. J. Bacteriol. 89: 897-898.

Seno, T., 1962 Genetical studies on copper resistance of Saccharomyces cerevisiae. Japan. J. Genetics 37: 207-217.

Sherman, F., and P. P. Slonimski, 1964 Respiration-deficient mutants of yeast. II. Biochemistry. Biochim. Biophys. Acta 90: 1-15.

Slonimski, P. P., 1953 La Formation des enzymes respiratoires chez la levure. Actualités Biochimiques. No. 17. Masson et Cie. Paris.

Zimmerman, F. K., P. Schwaier, and U. V. Laer, 1966 Mitotic recombination induced in Saccharomyces cerevisiae with nitrous acid, diethylsulfate and carcinogenic, alkylating nitrosoamides Z. Vererbungsl. 98: 230-246. 